\title{
Performance analysis firm operating in the sector of IT services through the model HGN
}

\author{
Eduard Hyránek ${ }^{1, *}$, Branislav Mišota ${ }^{2}$ \\ ${ }^{1}$ Faculty of Business Management, University of Economics in Bratislava, Dolnozemská cesta $1 / \mathrm{b}$, \\ 85235 Bratislava, Slovakia \\ ${ }^{2}$ Institute of Management, Slovak University of Technology in Bratislava, Vazovova 5, 81243 \\ Bratislava, Slovakia
}

\begin{abstract}
In this paper, we will briefly explain the application of the HGN model designed to measure performance, on the example of a selected non-financial corporation operating in the Slovak Republic. The aim of the paper is the application of the HGN model to IBM Slovakia Ltd. for the period from 2017 to 2019.At the same time, we will point out some difficulties in the application and the possibilities of improving the model.
\end{abstract}

\section{Introduction}

The HGN model [1] is the result of scientific research by the Faculty of Business Management of the University of Economics in Bratislava developed within the scientific project on the topic Verification and implementation of business performance modeling in financial decision making tools as a tool for financial decision-making [2, 3, 4]. In the field of research on the implementation of key determinants of performance models, there is a wide range of approaches at home [5,6] and abroad [7 - 10].

From the application of the HGN model so far in our scientific research, we have gradually found that it is necessary to adjust some financial ratios operating in the model and adapt them to industry specifics. A skilled workforce has a major role to play in this sector $[11,12]$. The information technology industry is a highly specific performance assessment industry $[13,14,15]$. For the purposes of the research, we selected a company from the information technology industry of IBM Slovakia Ltd. From the most recent data available as of April 2020, obtained from the register of financial statements for the period from 2017 to 2019, we analyzed the application of the HGN model.

\section{The aims and methods}

The aim of the paper is to assess the performance of IBM Slovensko s.r.o. based on an analysis based on the HGN model. We currently use two versions of the model. In this article, we focus on the HGN1 version. We will point out the possibility of its practical application. In addition to the practical application of the HGN model, we will evaluate the

\footnotetext{
* Corresponding author: eduard.hyranek@euba.sk
} 
possibility of modification of some financial indicators contained in the model on the example of this company.

\section{Results and Discussion}

In current scientific research, we have been dealing with business performance modeling since 2015. The performance models and predictions used in the theory and practice used so far do not sufficiently take into account the picture of the financial performance of the company in the current conditions of the Slovak economy. Several prediction models are created for completely different conditions than in the Slovak Republic [7 - 10].

The current economic situation of companies in the Slovak Republic is characterized by considerable indebtedness and, as a result, a high level of funds in receivables. Another factor is the insufficient use of the company's assets. It is these factors that adversely affect the efficiency of the company are emphasized in the HGN model. The more the company is indebted to long-term debts and has a high commitment of funds in receivables, the lower its final value.

\subsection{Model HGN1 version}

Out of 47 ratios, we created two sets of indicators (Figure 1), the first contains three efficiency indicators (xi) and the other three demandingness indicators (yi). We interconnect these indicators; or rather synthesize them, into one comprehensive performance indicator.

The aim is to objectively reflect the financial situation of an enterprise, its performance and to enable comparative assessment of the financial results of enterprises. At the first stage, we verified the following six financial ratios for the HGN1 version [2, 3, 4].
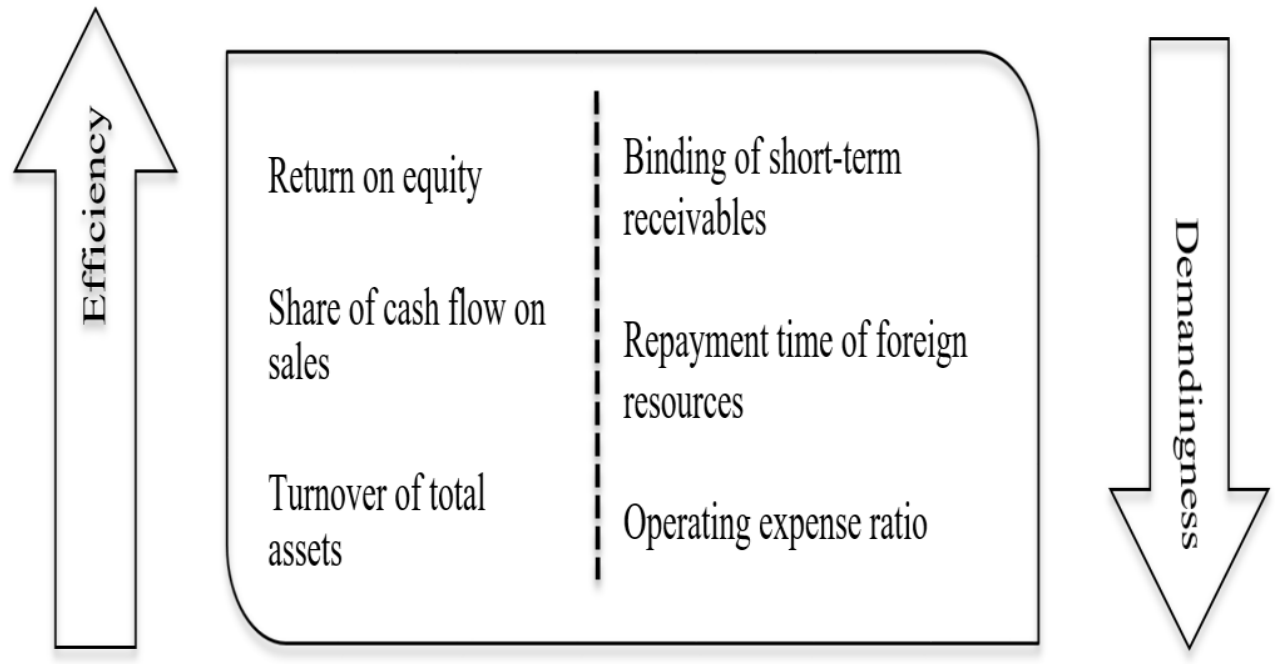

Fig. 1. The input indicators for creation of the HGN1 version

Source: Own research 
The aggregate efficiency indicator xi :

$\sum_{i=1}^{3} x_{i}$

will provide a partial picture of the company's performance in terms of efficiency.

The aggregate demandingness indicator yi:

$\sum_{i=1}^{3} y_{i}$

will provide a partial picture of the company's performance in terms of demandingness.

The synthetic indicator (SI) is to be influenced by the values of six indicators. It is defined as follows:

$$
S I=\sum_{i=1}^{3} x_{i}-\sum_{i=1}^{3} y_{i}
$$

\subsection{Application of the HGN1 performance model to IBM Slovakia Ltd.}

Table 1 lists selected IBM Slovakia Ltd. Assets entering into the calculations of the ratios of the determinants of the HGN1 performance model.

Table 1. Assets - Data from the company's financial statements for the years 2017-2019.

\begin{tabular}{|c|c|c|c|}
\hline \multirow{2}{*}{} & \multicolumn{3}{|c|}{ Assets } \\
\cline { 2 - 4 } & \multicolumn{3}{|c|}{ Data from the fin. stat. (in thousands of $€$ ) } \\
\hline Year & $\mathbf{2 0 1 7}$ & $\mathbf{2 0 1 8}$ & $\mathbf{2 0 1 9}$ \\
\hline $\begin{array}{c}\text { Total Assets } \\
\text { Current receivables - } \\
\text { total }\end{array}$ & 39816 & 38537 & 39477 \\
\hline
\end{tabular}

Source: The Register of Financial Statements (2020)

Table 2 lists selected Liabilities and Equity of IBM Slovakia Ltd. entering into the calculations of ratios of determinants of the HGN1 performance model. 
Table 2. Liabilities and Equity - Data from the company's financial statements for the years 20172019.

\begin{tabular}{|c|c|c|c|}
\hline & \multicolumn{3}{|c|}{ Liabilities and Equity } \\
\cline { 2 - 4 } & \multicolumn{2}{|c|}{ Data from the fin. stat. (in thousands of $€$ ) } \\
\hline Year & $\mathbf{2 0 1 7}$ & $\mathbf{2 0 1 8}$ & $\mathbf{2 0 1 9}$ \\
\hline $\begin{array}{c}\text { Equity } \\
\text { accounting period after } \\
\text { tax }\end{array}$ & 13517 & 10994 & 12828 \\
\hline $\begin{array}{c}\text { Liabilities } \\
\text { Net profit / loss for the }\end{array}$ & 32690 & 8705 & 10539 \\
\hline $\begin{array}{c}\text { Current liabilities - } \\
\text { total }\end{array}$ & 20699 & 15992 & 15289 \\
\hline
\end{tabular}

Source: The Register of Financial Statements (2020)

Table 3 presents selected indicators from the Income Statement of IBM Slovakia Ltd. entering into the calculations of ratios of determinants of the HGN1 performance model.

Table 3. Income Statement - Data from the company's financial statements for the years 2017-2019.

\begin{tabular}{|c|c|c|c|}
\hline \multirow{2}{*}{} & \multicolumn{3}{|c|}{ Income Statement } \\
\cline { 2 - 4 } & \multicolumn{3}{|c|}{ Data from the fin. stat. (in thousands of $€$ ) } \\
\hline Year & $\mathbf{2 0 1 7}$ & $\mathbf{2 0 1 8}$ & $\mathbf{2 0 1 9}$ \\
\hline Revenue & 105683 & 98565 & 98414 \\
\hline Amortization & 1337 & 1651 & 2038 \\
\hline Added value & 44066 & 47071 & 49444 \\
\hline $\begin{array}{c}\text { Cost of merchandise } \\
\text { sold }\end{array}$ & 5545 & 5631 & 7092 \\
\hline Production costs & 56070 & 45862 & 41877 \\
\hline $\begin{array}{c}\text { Personnel expenses - } \\
\text { total }\end{array}$ & 38395 & 39483 & 40650 \\
\hline \begin{tabular}{c} 
Taxes and fees \\
\hline
\end{tabular}
\end{tabular}

Source: The Register of Financial Statements (2020) 
Table 4 lists the IBM Slovakia Ltd. financial ratios included in the calculations of the HGN 1 ratios in group xi, (efficiency indicators).

Table 4. Aggregate indicators xi

\begin{tabular}{|c|c|c|c|}
\hline & \multicolumn{3}{|c|}{ Aggregate indicators xi } \\
\cline { 2 - 4 } & \multicolumn{3}{|c|}{ Year } \\
\hline Year & $\mathbf{2 0 1 7}$ & $\mathbf{2 0 1 8}$ & $\mathbf{2 0 1 9}$ \\
\hline Return on equity & 0,7918 & 0,8216 & 0,8778 \\
\hline $\begin{array}{c}\text { Share of cash flow on } \\
\text { sales }\end{array}$ & 0,0950 & 0,1237 & 0,1877 \\
\hline Turnover of total assets & 2,6543 & 2,5577 & 2,4929 \\
\hline
\end{tabular}

Source: Own research

Table 5 shows the financial ratios of IBM Slovakia Ltd. entering into the calculations of the ratio indicators of the HGN 1 model in group yi, (demandingness indicators).

Table 5. Aggregate indicators yi.

\begin{tabular}{|c|c|c|c|}
\hline & \multicolumn{3}{|c|}{ Aggregate indicators yi } \\
\cline { 2 - 4 } & \multicolumn{3}{|c|}{ Year } \\
\hline Year & $\mathbf{2 0 1 7}$ & $\mathbf{2 0 1 8}$ & $\mathbf{2 0 1 9}$ \\
\hline $\begin{array}{c}\text { Binding of short-term } \\
\text { receivables }\end{array}$ & 0,2868 & 0,2572 & 0,3140 \\
\hline $\begin{array}{c}\text { Repayment time of } \\
\text { foreign resources }\end{array}$ & 1,2776 & 0,8548 & 0,4747 \\
\hline $\begin{array}{c}\text { Operating expense } \\
\text { ratio }\end{array}$ & 1,0659 & 1,0396 & 1,0368 \\
\hline
\end{tabular}

Source: Own research

Table 6 shows the financial ratios of IBM Slovakia Ltd. entering into the calculations of ratios of the HGN 1 model in group xi i. efficiency indicators and yi, i. efficiency indicators and a synthetic indicator SI. 
Table 6. Synthetic indicator for model HGN1.

\begin{tabular}{|c|c|c|c|}
\hline \multirow{2}{*}{} & \multicolumn{2}{|c|}{ Synthetic indicator for model HGN1 } \\
\cline { 2 - 4 } & \multicolumn{3}{|c|}{ Year } \\
\hline Year & $\mathbf{2 0 1 7}$ & $\mathbf{2 0 1 8}$ & $\mathbf{2 0 1 9}$ \\
\hline$\sum_{i=1}^{3} x_{i}$ & 3,5411 & 3,5029 & 3,5584 \\
\hline$\sum_{i=1}^{3} y_{i}$ & 2,6303 & 2,1516 & 1,8255 \\
\hline$S I=\sum_{i=1}^{3} x_{i}-\sum_{i=1}^{3} y_{i}$ & 0,9108 & 1,3514 & 1,7330 \\
\hline
\end{tabular}

Source: Own research

Figure 2 shows the development of aggregated indicators xi and yi and a synthetic indicator from IBM Slovakia Ltd. for the HGN 1 model.

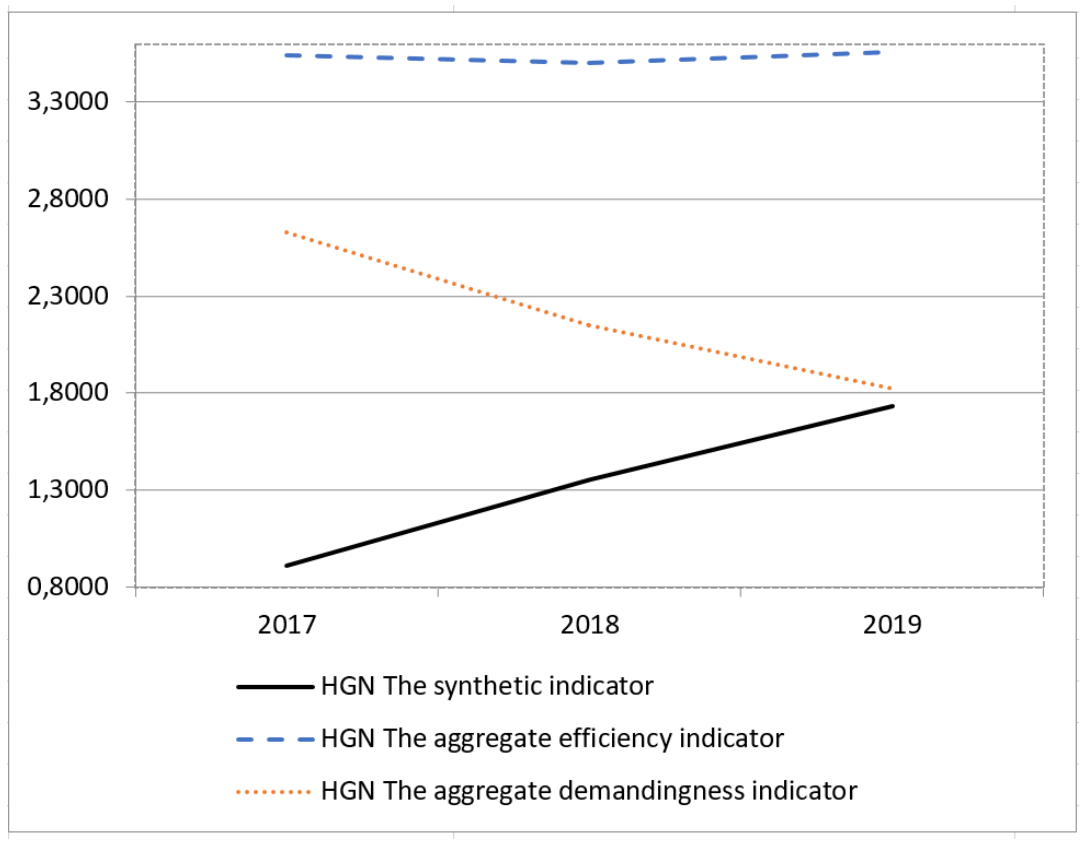

Fig. 2. Graph of aggregate indicators xi and yi and synthetic indicator for model HGN1.

Source: Own research

Based on the calculated data, the resulting values of aggregated indicators and coefficients, and finally from the synthetic indicator HGN, we can easily evaluate the performance of the surveyed company. The development trend of the company's 
performance measured by the synthetic indicator was favorable for the evaluated period. It can be stated that the indicators of efficiency xi had a balanced trend without significant fluctuations in the individual years evaluated. This can also be seen in individual indicators (Return on equity, Share of cash flow on sales, Turnover of total assets). Their development trend is basically balanced.

The synthetic indicator is significantly improved by the yi indicators, - indicators reducing efficiency. Their trend is decreasing in the evaluated years. This is a very favorable trend. This also confirms the correctness and objectivity of the principle of the HGN model. It contains indicators that generally have an adverse effect on efficiency. At IBM Slovakia Ltd, reducing them has a positive effect on overall performance and efficiency. The exception is indicator y1 (Binding of short-term receivables), which deteriorated slightly in 2019. Its deterioration did not have a significant effect on the positive trend.

An important indicator - net profit, there was no growing trend for the period under review. Due to the improving trend of efficiency-reducing indicators, the synthetic indicator did not deteriorate.

The HGN model emphasizes the long-term indebtedness of the company. The surveyed company does not have long-term debts, so the synthetic indicator is also positive.

\section{Conclusion}

Using the analysis presented in the research results in the previous section, we verify the accuracy and objectivity of the inclusion of individual indicators in the model. However, it should be noted that some indicators would require more precise calculation of their values. The absence of data drawn only from the annual financial statements does not allow this. We also verified the correctness of the inclusion of individual indicators in the model at this company. By obtaining more detailed data from the accounting records, it is possible to refine the results. The data contained in the model resulting from the flow variables are for the whole year and the stock variables as of the last day (31.12.) of the year.

We see a certain inaccuracy in this. For example, indicator x 3 Turnover of total assets would express a more objective assessment of the average values for individual months of the year. Between the average of the year and the final state as of 31.12. there may be a difference. Similarly, in indicator y1 The binding of short-term receivables can be analogously different. During the year, the amount of short-term receivables may be much lower than at the end of the year or vice versa. The calculation methods used in the model can clearly affect the overall result. Every company can eliminate this problem, because it also has data from monthly financial statements.

The analysis of indicators contained in the HGN model in various companies provides us with the opportunity to verify the correctness or even incorrectness of the method of their calculation. This is also confirmed by the surveyed IBM company. In some indicators, it will be necessary to modify the calculation method.

The article is a partial result of research within the VEGA project. 1/0462/19 "Implementing key determinants into performance models as tools financial management under the current conditions".

\section{References}

1. E. Hyránek, M. Grell, L. Nagy, I. Durinová, The Economic-mathematical Nature of the HGN Model Concept as a Tool for Measuring Performance of Enterprises. Ekonomický časopis 66, 3, 309-325. (2018). 
2. E. Hyránek, M. Grell, L. Nagy, Nové trendy merania výkonnosti podniku pre potreby finančných rozhodnutí. Bratislava, Ekonóm (2014).

3. E. Hyránek, M. Grell, L. Nagy, I. Implementácia modelu výkonnosti vo finančnom rozhodovaní podniku: model HGN ako nástroj finančného plánu. Praha, Nakladatelství Baset (2017).

4. M. Grell, E. Hyránek, P Maticové modely na meranie výkonnosti produkčných systémov. E a M: Ekonomie a Management 15, 1, $73-87$ (2012).

5. B. Gavurova, et al, (2017). Predictive potential and risks of selected bankruptcy prediction models in the Slovak business environment. Journal of Business Economics and Management 18, 6, 1156-1173. (2017).

6. R. Delina, M. Packová, Prediction Bankruptcy models validation in Slovak business environment. E a M: Ekonomie a Management 16, 3, 101-112 (2013).

7. E. I. Altman, Financial Ratios, Discriminant Analysis and the Prediction of Corporate Bankruptcy. Journal of Finance 23, 4, 589-609 (1968).

8. E. I. Altman, M. Iwanicz-Drozdowska, E. K. Laitinen, A. Suvas, Financial distress prediction in an international context: A review and empirical analysis of Altman's Z-score model. Journal of International Financial Management \& Accounting 28, 2, 131-171 (2017).

9. E. I. Altman, E. I., A. Saunders, Credit risk measurement: Developments over the last 20 years. Journal of banking \& finance 21 (11-12 (1997).

10. S. Ashraf, E. GS Félix, Z. Serrasqueiro, Do Traditional Financial Distress Prediction Models Predict the Early Warning Signs of Financial Distress? Journal of Risk and Financial Management 12, 2, 55 (2019).

11. J. Brown, D. A. Matsa, Boarding a sinking ship? An investigation of job applications to distressed firms. The Journal of Finance 71, 2, 507-550 (2019).

12. P. Bolton, N. Wang, J. Yang, Optimal contracting, corporate finance, and valuation with inalienable human capital. The Journal of Finance 74, 3, 1363-1429 (2019).

13. M. Jain, Y. Karmakar, Capital structure: An empirical study of choices and strategies for Indian service sector companies. Finance India 32, 4, 1227-1252. (2018).

14. S. Mithas, A. Tafti, , I. Bardhan J. M. Goh, Information technology and firm profitability: mechanisms and empirical evidence. MIS Quarterly 36, 1, 205-224 (2012).

15. K. Merkley, R. Michaely, J. Pacelli, Does the scope of the sell-side analyst industry matter? An examination of bias, accuracy, and information content of analyst reports. The Journal of Finance 72, 3, 1285-1334 (2017). 